combustion is determined by the rate at which air and fuel come into contact. With lump fuel this can be accelerated mechanically, but with powdered fuel actually moving with the air stream, it is difficult to secure relative motion between the two and probably diffusion is the limiting factor. Turbulence may promote mixing, but not necessarily accelerate diffusion. At the Fuel Research Station an attempt has been made to secure rapidity of combustion by the design of a 'grid' burner so constructed that the primary air and the fuel are fed in a number of thin layers with secondary air sandwiched in between them. The burner air is cooled by tertiary air introduced at the periphery. With this burner and the coal of volatile matter content down to 21 per cent, satisfactory and flexible combustion was attained with a compact flame. The satisfactory nature of the combustion is indicated by the low proportion of carbon-7 per cent-found in the ash leaving the furnace. The results of tests of this burner form the subject of Fuel Research Technical Paper No. 36, "Pulverised Fuel-the "Grid" Burner" (H.M.S.O. 6d. net).

\section{Tabular Data on Photographic Films}

THE Jahrbuch des Meteorologischen Observatoriums auf dem Donnersberge (Böhmen) for 1929, edited by Dr. Pollak, is a very slender volume compared with its predecessors. The explanation is that, partly from motives of economy, the usual tables which make up most of the volume have not been printed. Instead they have been typed, and the typescript has been 'filmed' on Agfa non-inflammable films, the whole of the tabular matter being set out in a continuous ribbon made up of individual pictures $18 \mathrm{~mm}$. wide and $24 \mathrm{~mm}$. in height which accompanies the printed portion in a small tin box. This ribbon, which measures considerably less than 2 motres in length, can be rolled into a compact cylinder of cross section less than $2 \mathrm{~cm}$. in diameter and in that form occupies less space than a small box of matches, the weight being extremely small. It is evident that had the whole year-book been treated in the same way the above rough description of its size and weight would still have applied to it, whereas the corresponding volumes for previous years are nearly 1 centimetre thick, and have pages measuring $31 \mathrm{~cm} . \times$ $23 \mathrm{~cm}$. In the 1928 volume Dr. Pollak discussed the method of reproduction of his year-books by filming. He illustrates and describes there an apparatus manufactured by Askania-Werke A.G., Berlin-Friedenau, with the aid of which successive portions of the reel are strongly illuminated and can be brought under a powerful magnifier, but this arrangement appears very awkward for anyone using a table at one end of the film and requiring to make frequent reference to tables at the other end. It is not easy to see how this difficulty can be surmounted-the provision of fast and slow movements corresponding with the coarse and fine adjustments of a microscope would not be a complete solution.

The need for rapid cross-reference in certain types of work appears to us to be so great that, until it can be met, it is superfluous to enlarge on the many virtues possessed by this photographic system (for example the ease with which books made in this way can be used with the aid of a lantern in teaching or public lecturing, the saving in postage when sending 'books' by post, and the saving in costs of publication). Moreover, another important drawback is that in a library composed of such books, there would have to be enough magnifiers and illuminators to supply the needs of all persons who might wish to use the library at the same time. It is an interesting venture, and one is left to wonder whether the growing difficulty of so many librariesthat of finding accommodation for such an increasingly massive accumulation of written knowledgemay not focus attention more and more on to revolutionary lines of development such as the one indicated by Dr. Pollak. Improvements in the quality of cinematograph films may make possible a much greater reduction of size, and the use of some system of magnification yielding a large field of view might lead to the abandonment of the reel form of film and conceivably open up ways of making cross reference easier in the new than in the old system.

\section{Importation of Plants into Great Britain}

THE Ministry of Agriculture has recently strengthened the regulations governing the importation of plants into England and Wales by a new order, entitled "The Importation of Plants Order of 1933" (London : H.M. Stationery Office. 2d, net). This came into operation on July 15 , and requires all imported consignments of living plants and parts thereof (except seeds) for planting, and all potatoes, to have been officially examined by the authorities of the country in which they were grown and certified as having been found to be healthy and free from any evidence of the presence of any insect or fungus pest destructive to agricultural or horticultural crops. This requirement is not limited as in the previous regulations to plants "with a persistent woody stem above ground", but applies to all classes of living plants. An additional certificate is required, as hitherto, in respect of plants grown in France, to the effect that the Colorado beetle has not been known to exist within 200 kilometres of the place where the plants, etc., were grown. The order provides for the treatment of consignments which arrive without the necessary certificates of health. Additional regulations are enforced to safeguard potatoes from wart disease and also in regard to cider apples imported between March 15 and October 14, while restrictions are continued on the importation of raw apples grown in the United States.

\section{Increase of Canadian Plains Bison}

IN 1907 the Pablo herd of 716 American bison, the remnant of the innumerable multitudes of a century before, was purchased by the Canadian Government. Of these, 631 were established in Buffalo National Park and the remainder formed the basis of a herd, now more than a thousand strong, in Elk Island National Park. Since the 
establishment of the Buffalo Park herd the numbers have increased rapidly: in all, 6,673 have been shipped alive to be established in the northern Wood Buffalo Park in the North West Territories ; including those of 1932, a total of 8,680 have been slain, and the meat, hides and heads disposed of ; and there remain in Buffalo Park 6,300 individuals. So that the minimum total of individuals bred there from the original 631 is 21,653 ; but many must have died a natural death (and there are persistent rumours of tuberculosis in the herd) and there may have been an increase also in Wood Buffalo Park. The experiment of transferring one race of bison, the plains variety, to the sole territory of another and dwindling race, the wood bison, was viewed with much concern by naturalists when it began in 1925 , and it would be reassuring if the Department of the Interior of Canada would issue some information, not only about the welfare of the transferred animals (which they have done), but about the welfare of the wood bison the territory of which was invaded, and about the chances or reality of cross-breeding between the two forms.

\section{Men of the Trees}

Whilst a forest officer in East Africa, Mr. St. Barbe Baker formed a small society, which he named the 'Men of the Trees', to encourage the tribesmen to curtail the thoughtless, wasteful destruction of the forests which is still so common a feature in many parts of the world. On his return home, Mr. Baker started the Association bearing this name (The Men of the Trees) in Great Britain, the Association now being in its ninth year. The broad aim of the Men of the Trees, as exemplified by the motto, is "To develop a tree sense in every citizen and to encourage all to plant, protect and love trees everywhere", is applicable to many parts of the British Empire. The Society's object is even wider for it "not only encourages the protection, preservation and beautifying of the countryside, since no village or landscape can be complete without its trees-but its range is both national, imperial and international. It appeals equally to all creeds and to all classes". Enthusiasm for the tree in its many varying degrees of importance is the main note and its claims to form a point of union for all those to whom trees and the life of trees have an instinctive appeal. Probably, one of its most valuable activities, so far as the future is concerned, is the endeavour to interest the young people, guides, scouts and school children generally, in tree-planting and the protection of planted trees. The address of the Secretary of the Association is 32 Warwick Road, London, S.W.1.

\section{Lost Birds of Madagascar}

IN addition to two short articles dealing with the preservation of wild life in Sierra Leone and Gambia, and a summary of the very important report of the Malaya Commission, the current number of the Journal of the Society for the Preservation of the Fauna of the Empire contains a discussion concerning two little-known extinct birds of Madagascar. The 'poulet rouge', a flightless bird with a kiwi-like appearance, and the 'corbeau indien', a stout-bodied, parrot-like bird with a crest upon its forehead, are unknown except for some odd bones and a few contemporary drawings. Dr. Graham Renshaw has collected the meagre information which exists about these curious birds, one apparently a ground bird, the other arboreal, and has illustrated his description by representations of the birds as they appear to have existed.

\section{Development of the Lightning Discharge}

Referring to the letter in Nature of September 9, p. 407, by Schonland and Collens on the development of the lightning discharge, Mr. S. E. Ashmore, 22, Soho Road, Birmingham, 21, writes to suggest that the noise heard in a wireless receiver during a storm affords confirmatory evidence. The first 'click', heard a fraction of a second before the actual flash is seen (Meteorol Mag., 68, 114, 139; 1933), may be due to the preliminary downward avalanche of electrons. The lightning flash 'heard' afterwards is that which Schonland and Collens describe as progressing by thermal ionisation.

\section{Announcements}

Dr. Herbert E. Ives, of the Bell Telephone Laboratories, New York, will deliver the Thomas Young oration before the Physical Society at the Royal Institution, 21, Albemarle Street, London, W.1, on October 6. Dr. Ives's subject will be "Thomas Young and the Simplification of the Artist's Palette".

Messrs. Bernard Quaritch, Ltd., 11 Grafton Street, New Bond Street, W.1, have issued a new catalogue (No. 475) containing a selection of books on zoology and geology. The catalogue contains 1,966 items, the largest section being that of entomology, which contains some important works from the libraries of Ernest and Léon Candèze.

Applicatrons are invited for the following appointments, on or before the dates mentioned :-A temporary assistant lecturer in mathematics at the University of Leeds -The Registrar (Sept. 27). A horticultural adviser in Jersey-The Greffier of the States, States' Greffe Office, Royal Square, St. Helier, Jersey (Sept. 30). A librarian for the Pharmaceutical Society of Great Britain, 17, Bloomsbury Square, London, W.C.1-The Secretary (Oct. 3). A technical assistant for the Southend Educa tion Committee-The Director of Education, Education Office, 20, Warrior Square, Southend-on-Sea (Oct. 4). An advisory officer on farm economics for the Department of Agriculture for ScotlandThe Establishment Officer, Department of Agriculture for Scotland, York Buildings, Edinburgh, 2 (Oct. 12). A professor of anthropology at the University of Sydney-The Registrar (Dec. 2.-Further particulars from the Universities Bureau of the British Empire, 88a, Gower Street, London, W.C.1).

ERratum.--Prof. Hans Schinz, of Zurich, informs us that Dr. Otto Stapf died at 6.30 a.m. on August 4 and not on August 3, as stated in NATURE of August 26. 